\title{
PENGEMBANGAN PROTOTIPE PEMBELAJARAN MATEMATIKA KOMPUTASI MENGGUNAKAN MODEL KOOPERATIF TIPE STAD
}

\author{
Apriyanto $^{28}$ \\ Dosen Fakultas Teknik Universitas Andi Djemma Palopo
}

\begin{abstract}
Abstrak: Penelitian ini adalah penelitian pengembangan (Research and Development) dengan ujicoba terbatas yang bertujuan untuk mengembangkan prototipe pembelajaran menggunakan model kooperatif tipe STAD pada matakuliah Matematika Komputasi yang meliputi Buku Ajar Mahasiswa (BM), Lembar Kegiatan Mahasiswa (LKM), Rencana Pelaksanaan Pembelajaran (RPP), dan Tes Hasil Belajar (THB) sehingga menghasilkan prototipe pembelajaran yang valid, efektif, dan praktis. Subjek penelitian ini adalah mahasiswa semester II prodi Teknik Informatika Fakultas Teknik Universitas Andi Djemma dengan jumlah mahasiswa sebanyak 41 orang, jumlah pertemuan di kelas sebanyak enam kali dengan tes hasil belajar mahasiswa satu kali. Prosedur pengembangan yang digunakan dalam penelitian ini mengadopsi model Thiagarajan atau model 4-D yang dimodifikasi meliputi empat tahap, yaitu tahap pembatasan (Define), perancangan (Design), pengembangan (Develop), dan penyebaran (Disseminate). Prototipe pembelajaran Matematika Komputasi menggunakan model kooperatif tipe STAD yang dikembangkan telah divalidasi oleh pakar serta mengalami revisi berulang kali sehingga didapatkan hasil yang valid dan efektif untuk digunakan. Hasil dari ujicoba terbatas ini menunjukkan bahwa (1) skor rata-rata yang diperoleh mahasiswa pada tes hasil belajar adalah 73,05 dari skor ideal 100 dengan standar deviasi 13,95. Terdapat 32 dari 41 mahasiswa atau sekitar 78,05\% memenuhi ketuntasan individu yang menunjukkan bahwa ketuntasan klasikal tercapai; (2) penerapan prototipe pembelajaran model kooperatif tipe STAD mampu meningkatkan minat serta motivasi mahasiswa dalam memahami konsep matematika komputasi; (3) pada umumnya mahasiswa memberikan respons positif terhadap prototipe pembelajaran kooperatif tipe STAD yang digunakan; (4) dosen dapat membimbing kelompok bekerja dan belajar; dan (5) tingkat kemampuan dosen dalam mengelola proses pembelajaran kooperatif tipe STAD termasuk dalam kategori sangat tinggi dengan rata-rata yang diperoleh adalah 3,51 artinya penampilan dosen dapat dipertahankan.
\end{abstract}

Katakunci: Prototipe Pembelajaran, Matematika Komputasi, Model Kooperatif Tipe STAD

Abstract: This research and development with limited testing intended to develop
learning Prototype with cooperative model STAD type on Mathematics of
Computation which cover Students' book, students' activity sheet, lesson plan, and
results of the learning test to it produces learning prototype which are valid,
effective, and practical. Research subjects were the student Second Semester at
Department of informatics engineering, faculty of Engineering Universitas Andi
Djemma with the total students is 41 . The total meeting in the classroom was six
times with learning test once. Developed procedure used in this research was
Thiagarajan model or 4-D model which covered 4 stages, namely, define, design,
develop, and, disseminate. However, the disseminate stage was not conducted due
to this was barely limited testing. Mathematics of Computation learning Prototype
with cooperative model STAD type were validated by experts as well as got revised

${ }^{28}$ Apriyanto. Lecturer at Universitas Andi Djemma Palopo 
repeatedly so that the results were valid and effective to use. The result of this limited testing shows that (1) the average score obtained of students in the learning test is 73.05 from ideal score 100 with the deviation standard 13.95. there are 32 out of 41 students or similarly $78.05 \%$ have satisfied the individual completeness which shows that classical completeness is achieved; (2) by using learning package cooperative STAD type, students' interest and motivation in comprehending mathematical of Computation concepts are improved; (3) generally, students give positive responses towards learning package cooperative STAD type; (4) lecturer can guide work group and work study; and (5) lecturer's ability level in managing cooperative learning STAD type process is in very high level with the average score obtained is 3.51. This means that lectirer's appearance can be maintained.

Keywords: Learning Prototype, Mathematics of Computation, Cooperative Model STAD

\section{PENDAHULUAN}

Persoalan utama pendidikan adalah persoalan manusia, yaitu memanusiakan manusia menjadi lebih manusiawi. Memanusiakan manusia itu berkaitan dengan banyak hal, misalnya: bagaimana cara memanusiakan manusia itu, bagaimana bentuk komunikasi antara yang memanusiakan dan yang dimanusiakan, apa yang harus menetap dan yang harus berubah pada yang dimanusiakan, hasil macam apa yang harus dicapai dengan memanusiakan manusia itu, dsb (Arifin, 2005:1).

Kualitas pendidikan dan keterampilan dalam ilmu pengetahuan dan teknologi (IPTEK), berjalan searah dengan peningkatan sumber daya manusia yang berimplikasi terhadap kemajuan sebuah bangsa dan Negara. Pendidikan di Indonesia bertujuan untuk mencerdaskan kehidupan bangsa. Tujuan itu dapat tercapai melalui penataan pendidikan yang baik.

Berbagai upaya telah dilakukan oleh pihak yang berkompeten dalam bidang pendidikan untuk meningkatkan mutu pendidikan di Indonesia. Upaya-upaya tersebut mencakup hampir disetiap komponen pendidikan seperti penyempurnaan kurikulum pendidikan, peningkatan kemampuan dosen, pengadaan media belajar mengajar, penataan organisasi, dan manajemen pendidikan serta usaha-usaha lain yang berkenaan dengan peningkatan mutu dan kualitas pendidikan.

Matematika merupakan salah satu disiplin ilmu murni yang mempunyai peranan penting dalam peningkatan mutu pendidikan. Oleh Karena itu, pembelajaran matematika mutlak diajarkan kepada semua mahasiswa bahkan sejak dari jenjang taman kanak-kanak (TK) untuk membekali mereka dengan kemampuan berpikir logis, analitis, sistematis, kritis dan kreatif serta kemampuan bekerja sama. Hal ini sejalan dengan pernyataan Galileo Galilei (1564-1642) sebagai berikut:

"Alam semesta itu bagaikan sebuah buku raksasa yang hanya bisa dibaca jika orang bisa mengerti bahasanya, akrab dengan lambang dan huruf yang dipakai di dalamnya. Dan bahasa alam semesta itu tidak lain adalah Matematika".

Sebahagian mahasiswa masih menganggap matematika komputasi sebagai matakuliah yang sangat sulit dibandingkan dengan matakuliah lainnya, hal ini disebabkan kurangnya prototype pembelajaran matematika komputasi yang ada. Oleh karena itu, minat dan motivasi pada kuliah matematika komputasi terlihat jelas berbeda (tinggi atau 
rendah) untuk masing-masing mahasiswa. Akibatnya, prestasi dan daya serap mahasiswa juga berbeda, sesuai dengan minat dan motivasinya.

Belajar akan lebih bermakna jika mahasiswa mengalami apa yang dipelajarinya, bukan hanya mengetahuinya. Pembelajaran yang berorientasi pada penguasaan materi terbukti berhasil dalam kompetisi mengingat jangka pendek tetapi gagal dalam membekali mahasiswa memecahkan persoalan dalam kehidupan jangka panjang (Direktorat Pembinaan SMP, 2006:1).

Dalam pembelajaran matematika komputasi, dosen masih menggunakan paradigma pembelajaran lama dalam arti komunikasi masih cenderung berlangsung satu arah (one way) umumnya dari dosen ke mahasiswa. Model dan Pendekatan Pembelajaran masih bersifat konvensional yang berpusat pada dosen (lecturer center) dengan dosen sebagai sumber belajar, akibatnya pembelajaran cenderung monoton dan mahasiswa cepat merasa jenuh. Oleh karena itu, dosen hendaknya lebih memilih berbagai variasi model, pendekatan, strategi, dan metode yang sesuai dengan situasi sehingga tujuan pembelajaran yang direncanakan akan tercapai. Perlu diketahui bahwa baik atau tidaknya suatu pemilihan model pembelajaran akan tergantung pada tujuan pembelajarannya, kesesuaian dengan materi pembelajaran, tingkat perkembangan mahasiswa, kemampuan dosen dalam mengelola pembelajaran serta mengoptimalkan sumber-sumber belajar yang ada.

Seorang pendidik atau dosen bukan hanya menyampaikan informasi kepada mahasiswanya, namun mempunyai tugas yang lebih kompleks. Bagaimana dosen dapat memotivasi seluruh mahasiswa mereka untuk belajar dan membantu saling belajar satu sama lain. Bagaimana dosen dapat menyusun kegiatan kelas sedemikian rupa sehingga mahasiswa akan berdiskusi, berdebat, dan menggeluti ide-ide, konsep-konsep, dan keterampilan-keterampilan sehingga mahasiswa benar-benar memahami ide, konsep, dan keterampilan tersebut. Bagaimana dosen dapat memanfaatkan energi sosial seluruh rentang usia mahasiswa yang begitu besar di dalam kelas untuk kegiatan-kegiatan pembelajaran produktif. Bagaimana dosen dapat mengorganisasikan kelas sehingga mahasiswa saling menjaga satu sama lain, saling mengambil tanggung jawab satu sama lain, dan belajar untuk menghargai satu sama lain terlepas dari suku, tingkat kinerja, atau ketidakmampuan karena cacat (Nur, 2005:1).

Pertanyaan-pertanyaan diatas merupakan cikal-bakal lahirnya model pembelajaran kooperatif. Model pembelajaran kooperatif atau dengan nama lain belajar bersama (learning together) merupakan salah satu model pembelajaran yang dapat membantu para mahasiswa meningkatkan sikap positif pada matakuliah matematika komputasi. Para mahasiswa secara individu membangun kepercayaan diri terhadap kemampuannya untuk menyelesaikan masalah-masalah matematika komputasi, sehingga akan mengurangi bahkan menghilangkan rasa cemas terhadap matematika (math anxiety) yang banyak dialami para mahasiswa.

Seiring dengan perkembangan IPTEK, ada beberapa tipe (pendekatan) dalam pembelajaran kooperatif. Salah satu di antaranya adalah tipe STAD (Student Teams Achievement Divisions). Pada tipe STAD, mahasiswa dalam satu kelas dipecah menjadi beberapa kelompok yang beranggotakan 4 sampai 6 orang mahasiswa. Setiap kelompok harus heterogen dalam artian, satu kelompok terdapat jenis kelamin, ras, etnik, maupun tingkat kecerdasan yang berbeda-beda. Sistem penilaian dilakukan terhadap kelompok, dan akan mendapatkan penghargaan (reward) jika kelompok mampu menunjukan 
prestasi yang dipersyaratkan. Model pembelajaran kooperatif tipe STAD, lebih menekankan pada kehadiran teman sebaya berinteraksi antar sesamanya sebagai sebuah kelompok dalam menyelesaikan atau membahas suatu masalah tugas.

\section{Rumusan Masalah}

Rumusan masalah dalam penelitian ini adalah bagaimana mengembangkan prototipe pembelajaran matematika komputasi menggunakan model kooperatif tipe STAD yang valid, praktis, dan efektif?

\section{Tujuan Penelitian}

Penelitian pengembangan ini bertujuan untuk mengembangkan prototipe pembelajaran matematika komputasi menggunakan model kooperatif tipe STAD yang valid, praktis, dan efektif. Prorotipe pembelajaran yang dimaksud ialah:

1. Buku Ajar Mahasiswa (BM)

2. Lembar Kerja Mahasiswa (LKM)

3. Rencana Pelaksanaan Pembelajaran (RPP)

4. Tes Hasil Belajar (THB)

\section{Pembelajaran Kooperatif}

Model pembelajaran kooperatif bukanlah hal yang sama sekali baru bagi dosen. Model ini merupakan suatu model pembelajaran yang mengutamakan adanya kelompokkelompok. Setiap mahasiswa yang ada dalam kelompok mempunyai tingkat kemampuan yang berbeda-beda (tinggi, sedang dan rendah) dan jika memungkinkan anggota kelompok berasal dari ras, budaya, suku yang berbeda serta memperhatikan kesetaraan jender. Model pembelajaran kooperatif mengutamakan kerja sama dalam menyelesaikan permasalahan untuk menerapkan pengetahuan dan keterampilan dalam rangka mencapai tujuan pembelajaran.

Menurut Nur (2005:1),

"Pembelajaran Kooperatif ialah dimana mahasiswa bekerja dalam kelompokkelompok kecil saling membantu belajar satu sama lainnya. Kelompok-kelompok tersebut beranggotakan mahasiswa dengan hasil belajar tinggi; rata-rata dan rendah; laki-laki dan perempuan; mahasiswa dengan latar belakang suku berbeda yang ada di kelas; dan mahasiswa penyandang cacat bila ada".

Suherman (2003:260) menambahkan, Cooperative Learning mencakup suatu kelompok kecil mahasiswa yang bekerja sebagai sebuah tim untuk menyelesaikan sebuah masalah, menyelesaikan suatu tugas, atau mengerjakan sesuatu untuk mencapai tujuan bersama lainnya. Namun, jika para mahasiswa duduk bersama dalam kelompokkelompok kecil tetapi menyelesaikan masalah sendiri-sendiri atau mempersilahkan salah seorang diantaranya untuk menyelesaikan seluruh pekerjaan kelompok tidak dapat dikategorikan Cooperative Learning.

Jadi, dapat disimpulkan bahwa pembelajaran kooperatif merupakan model pembelajaran yang menggunakan sistem pengelompokan/tim kecil, yaitu antara empat sampai enam orang yang mempunyai latar belakang kemampuan akademik, jenis kelamin, ras, atau suku yang berbeda (heterogen). Sistem penilaian dilakukan terhadap 
kelompok. Setiap kelompok akan memperoleh penghargaan (reward), jika kelompok mampu menunjukan prestasi yang dipersyaratkan.

\section{a. Tujuan pembelajaran kooperatif}

Tujuan utama yang diharapkan dapat dicapai dalam model pembelajaran kooperatif, (http://www.docstoc.com/docs/4779267/Pembelajaran-Kooperatif-Matematika.pdf) yaitu:

1) Prestasi akademik

Pembelajaran kooperatif sangat menguntungkan baik bagi mahasiswa berkemampuan tinggi maupun berkemampuan rendah. Bagi mahasiswa yang berkemampuan tinggi penguasaan materi akan semakin mendalam, sedangkan bagi mahasiswa berkemampuan rendah diharapkan mampu menguasai materi yang sebelumnya tidak mudah dipahami jikalau belajar sendiri.

2) Penerimaan terhadap keanekaragaman

Dengan berbagai perbedaan (heterogen) yang ditonjolkan dalam pemilihan anggota kelompok, akan mengarahkan mahasiswa untuk mengakui dan menerima perbedaan yang ada antara dirinya selaku individu dengan orang lain (sosial).

3) Pengembangan keterampilan sosial

Pembelajaran kooperatif bertujuan mengarahkan kepada keterampilanketerampilan kerjasama sebagai suatu tim. Keterampilan ini kelak akan sangat bermanfaat bagi mahasiswa ketika merekan berada di masyarakat.

Perlu disadari bahwa dalam proses pencapaian tujuan terdapat berbagai tantangan dan hambatan. Oleh karena itu, beberapa hal yang perlu dipenuhi dalam pelaksanaan pembelajaran kooperatif agar menjamin para mahasiswa bekerja secara kooperatif, yaitu (Suherman,2003:260):

a. Mahasiswa yang bergabung dalam suatu kelompok harus merasa bahwa mereka adalah bahagian dari suatu kelompok dan mempunyai tujuan bersama yang harus dicapai.

b. Para mahasiswa bergabung dalam suatu kelompok harus menyadari bahwa masalah yang mereka hadapi adalah masalah kelompok dan bahwa berhasil atau tidaknya kelompok itu akan menjadi tanggung jawab bersama oleh seluruh anggota kelompok itu.

c. Untuk mencapai hasil yang maksimum, para mahasiswa yang tergabung dalam kelompok, harus berbicara satu sama lain dalam mendiskusikan masalah yang dihadapi.

\section{b. Karakteristik pembelajaran kooperatif}

Slavin, Abrani, dan Chambers (1996) berpendapat bahwa belajar melalui kooperatif dapat dijelaskan melalui beberapa perspektif, yaitu perspektif motivasi, perspektif sosial, perspektif perkembangan kognitif, perspektif elaborasi kognitif (Sanjaya, 2007:242).

Perspektif motivasi artinya bahwa penghargaan yang diberikan kepada kelompok memungkinkan setiap anggota kelompok akan saling membantu. Perspektif sosial artinya bahwa melalui kooperatif setiap mahasiswa akan saling membantu dalam belajar karena mereka menginginkan semua anggota kelompok memperoleh keberhasilan 
Perspektif pengembangan kognitif artinya bahwa dengan adanya interaksi antara anggota kelompok dapat mengembangkan prestasi mahasiswa untuk berpikir mengolah berbagai informasi. Elaborasi kognitif, artinya bahwa setiap mahasiswa akan berusaha untuk memahami dan menimba informasi untuk menambah pengetahuan kognitifnya.

Dengan demikian, karakteristik pembelajaran kooperatif dapat dibedakan menjadi empat karakter, yaitu (Sanjaya, 2007:242):

1) Pembelajaran secara tim

Pembelajaran kooperatif adalah pembelajaran secara tim. Tim merupakan tempat untuk mencapai tujuan. Oleh karena itu, tim harus mampu membuat setiap mahasiswa belajar. Semua anggota tim harus saling membantu untuk mencapai tujuan pembelajaran. Untuk itulah, kriteria keberhasilan pembelajaran ditentukan oleh keberhasilan tim.

2) Didasarkan pada manajemen kooperatif

Pembelajaran kooperatif dijalankan sesuai dengan manajemen kooperatif. Sebagaimana pada umumnya, manajemen mempunyai empat fungsi pokok, yaitu fungsi perencanaan, fungsi organisasi, fungsi pelaksanaan, dan fungsi kontrol. Keempat fungsi pokok tersebut senantiasa menjiwai pembelajaran kooperatif.

3) Kemauan untuk bekerja sama

Keberhasilan pembelajaran kooperatif ditentukan oleh keberhasilan secara kelompok. Oleh sebab itu, prinsip bekerja sama perlu ditekankan dalam proses pembelajaran kooperatif. Setiap anggota kelompok bukan saja harus diatur tugas dan tanggung jawab masing-masing, akan tetapi juga ditanamkan perlunya saling membantu.

4) Keterampilan bekerja sama

Mahasiswa perlu didorong untuk mau dan mampu berinteraksi dan berkomunikasi dengan anggota lain. Mahasiswa perlu dibantu mengatasi berbagai hambatan dalam berinteraksi dan berkomunikasi, sehingga setiap mahasiswa dapat menyampaikan ide, mengemukakan pendapat, dan memberikan kontribusi kepada keberhasilan kelompok.

\section{c. Prinsip-prinsip pembelajaran kooperatif}

Terdapat empat prinsip dasar dalam pembelajaran kooperatif, yaitu (Sanjaya, 2007:242) :

1) Prinsip ketergantungan positif (Positive Interdependence)

Hakikat ketergantungan positif, artinya tugas kelompok tidak mungkin bisa diselesaikan manakala ada anggota yang tak bisa menyelesaikan tugasnya, dan semua ini memerlukan kerja sama yang baik dari masing-masing anggota kelompok. Oleh sebab itu, anggota kelompok yang mempunyai kemampuan lebih, diharapkan mau dan mampu membantu temannya untuk menyelesaikan tugasnya.

2) Tanggung jawab perseorangan (Individual Accountability)

Prinsip ini merupakan konsekuensi dari prinsip ketergantungan positif. Keberhasilan kelompok bergantung pada setiap anggotanya, maka setiap anggota kelompok harus memiliki tanggung jawab sesuai dengan tugasnya. Untuk 
mencapai hal tersebut, maka penilaian diberikan terhadap individu dan juga kelompok.

3) Interaksi tatap muka (Face to Face Promotion Interaction)

Interaksi tatap muka akan memberikan pengalaman yang berharga kepada setiap anggota kelompok untuk bekerja sama, menghargai setiap perbedaan, memanfaatkan kelebihan masing-masing anggota, dan mengisi kekurangan masing-masing.

4) Partisipasi dan komunikasi (Participation and Communication)

Kemampuan berpartisipasi aktif dan berkomunikasi sangat penting sebagai bekal mahasiswa dalam kehidupan di masyarakat kelak. Tidak semua mahasiswa mempunyai kemampuan berkomunikasi, misalnya kemampuan mendengarkan dan berbicara, padahal keberhasilan kelompok ditentukan oleh partisipasi setiap anggotanya. Oleh karena itu, pembelajaran kooperatif melatih setiap mahasiswa untuk mampu berpartispasi aktif dan berkomunikasi dengan baik.

\section{d. Langkah-langkah pembelajaran kooperatif}

Terdapat 6 langkah/fase utama yang harus diperhatikan dalam model pembelajaran kooperatif yang diuraikan dalam tabel berikut ini:

Tabel 1.

Langkah-langkah pembelajaran kooperatif

\begin{tabular}{|c|c|}
\hline Fase & Kegiatan Dosen \\
\hline $\begin{array}{l}\text { Fase-1 } \\
\text { Menyampaikan tujuan dan } \\
\text { memotivasi mahasiswa }\end{array}$ & $\begin{array}{l}\text { Dosen menyampaikan tujuan pembelajaran dan } \\
\text { mengkomunikasikan kompetensi dasar yang akan dicapai } \\
\text { serta memotivasi mahasiswa. }\end{array}$ \\
\hline $\begin{array}{l}\text { Fase-2 } \\
\text { Menyajikan informasi }\end{array}$ & $\begin{array}{l}\text { Dosen menyajikan informasi kepada } \\
\text { dengan peragaan (demonstrasi) atau teks. }\end{array}$ \\
\hline $\begin{array}{l}\text { Fase-3 } \\
\text { Mengorganisasikan } \\
\text { mahasiswa ke dalam } \\
\text { kelompok-kelompok } \\
\text { belajar. }\end{array}$ & $\begin{array}{l}\text { Dosen menjelaskan kepada mahasiswa bagaimana caranya } \\
\text { membentuk kelompok belajar dan membantu setiap } \\
\text { kelompok agar melakukan perubahan yang efisien. }\end{array}$ \\
\hline $\begin{array}{l}\text { Fase-4 } \\
\text { Membimbing kelompok } \\
\text { belajar }\end{array}$ & $\begin{array}{l}\text { Dosen membimbing kelompok-kelompok belajar pada saat } \\
\text { mereka mengerjakan tugas. }\end{array}$ \\
\hline $\begin{array}{l}\text { Fase-5 } \\
\text { Evaluasi }\end{array}$ & $\begin{array}{l}\text { Dosen mengevaluasi hasil belajar tentang materi yang telah } \\
\text { dipelajari atau masing-masing kelompok mempresentasikan } \\
\text { hasil kerjanya. }\end{array}$ \\
\hline $\begin{array}{l}\text { Fase-6 } \\
\text { Memberikan penghargaan }\end{array}$ & $\begin{array}{l}\text { Dosen mencari cara-cara untuk menghargai baik upaya } \\
\text { maupun hasil belajar individu dan kelompok. }\end{array}$ \\
\hline
\end{tabular}

\section{Student Teams Achievement Division (STAD)}

STAD dikembangkan oleh Robert Slavin dan teman-temannya di Universitas John Hopkins. Ide utama dibalik STAD adalah untuk memotivasi mahasiswa saling membantu dalam hal menguasai keterampilan-keterampilan yang diajarkan dosen. Tipe pembelajaran kooperatif merupakan yang paling sederhana karena mengacu kepada kelompok belajar mahasiswa, menyajikan informasi akademik baru kepada mahasiswa tiap minggunya menggunakan presentase verbal atau teks. 
Mahasiswa dalam satu kelas dipecah menjadi beberapa kelompok yang beranggotakan $4-5$ orang dan setiap kelompok harus heterogen, terdiri dari jenis kelamin, ras, etnik, maupun tingkat kecerdasan yang berbeda-beda. Dosen mempresentasikan sebuah pelajaran, kemudian anggota tim ini menggunakan lembar kegiatan atau perangkat pembelajaran yang lain untuk menuntaskan materi pelajaran dan kemudian saling membantu satu sama lain. Secara individual setiap minggu atau setiap 2 minggu mahasiswa diberi kuis kemudian diberi skor perkembangan.

Skor kuis mahasiswa tidak didasarkan pada skor mutlak mahasiswa tetapi berdasarkan seberapa jauh skor itu melampaui rata-rata skor mahasiswa yang lalu. Skor individu dijumlahkan untuk mendapatkan skor tim, dan tim-tim yang memenuhi kriteria tertentu dapat diberi sertifikat atau penghargaan lain. Keseluruhan siklus kegiatan ini, yaitu dari presentasi dosen sampai mengerjakan kuis biasanya memerlukan $3-5$ periode pertemuan.

Menurut Nur dkk (Pance, 2008:22), STAD memiliki ciri-ciri berikut ini:

a. Bahan pelajaran disajikan oleh dosen dan mahasiswa harus mencurahkan perhatiannya, Karena hal itu akan mempengaruhi hasil kerja mereka di dalam kelompok;

b. Anggota kelompok terdiri empat sampai lima orang mahasiswa, mereka heterogen dalam berbagai hal seperti prestasi akademik dan jenis kelamin.

c. Setelah tiga kali pertemuan diadakan tes individu berupa kuis mingguan yang harus dikerjakan mahasiswa sendiri-sendiri;

d. Materi pelajaran disiapkan oleh dosen dalam bentuk lembar kerja mahasiswa;

e. Penempatan mahasiswa dalam kelompok lebih baik ditentukan oleh dosen dari pada mereka memilih sendiri.

Model pembelajaran memiliki sintaks/langkah-langkah yang berbeda-beda. Setiap tipe pembelajaran kooperatif juga memiliki kekhasan dan perbedaan yang dapat dilihat pada sintaksnya. Pada $S T A D$, sintaks kegiatan pembelajaran terdiri atas 4 bagian, yaitu:

1) Mengajar : Mempresentasikan pelajaran,

2) Belajar dalam tim : Mahasiswa bekerja dalam tim mereka dengan dipandu oleh LKS untuk menuntaskan materi pelajaran,

3) Tes: Mahasiswa mengerjakan kuis atau tugas lain secara individual,

4) Penghargaan kelompok : Dosen memberikan penghargaan atas hasil kerja mahasiswa baik secara individual maupun kelompok.

Setelah satu siklus berjalan dengan penerapan pembelajaran kooperatif tipe STAD dalam kelas, dosen dapat mengatur ulang kelompok-kelompok baru untuk memberikan kesempatan kepada mahasiswa bekerja dengan teman sekelas yang lain dan menjaga program pengajaran tetap segar.

Tipe pembelajaran kooperatif yang digunakan dalam penelitian ini adalah tipe pembelajaran STAD dengan pertimbangan bahwa tipe ini, merupakan tipe yang paling sederhana atau dengan bahasa lain merupakan dasar atau pondasi tipe pembelajaran kooperatif lainnya. Selain itu mengacu kepada kelompok belajar mahasiswa dalam memahami semua materi pelajaran sehingga, Setiap mahasiswa akan termotivasi untuk saling membantu dalam hal menguasai keterampilan-keterampilan yang diajarkan dosen. 1) Pemilihan materi yang sesuai 
Dosen yang berpengalaman mengetahui dari pengalaman topik mana yang cocok untuk pembelajaran kooperatif seperti halnya mereka mengetahui perkiraan tingkat perkembangan mental dan minat mahasiswa di dalam kelas mereka.

\section{2) Pembentukan kelompok mahasiswa}

Tugas perencanaan penting lainnya untuk pembelajaran kooperatif ialah pembentukan kelompok mahasiswa. Tugas ini akan bervariasi tergantung kepada tujuan yang ingin dicapai oleh dosen untuk suatu pelajaran tertentu. Dengan demikian komposisi kelompok mahasiswa memiliki kemungkinan yang tidak terbatas. Selama fase perencanaan, para dosen harus menetapkan tujuan akademik dan tujuan sosial secara jelas.

\section{3) Pengembangan materi dan tujuan}

Pada saat dosen mempersiapkan suatu pelajaran pembelajaran langsung, maka salah satu tugas utamanya ialah mengumpulkan materi yang disampaikan dalam pesan verbal yang bermakna atau dalam bentuk demonstrasi yang disertai dengan keterampilan tertentu. Walaupun dosen memberi informasi verbal dalam pelajaran pembelajaran kooperatif, informasi ini umumnya disampaikan dalam bentuk teks, lembar kegiatan dan panduan belajar.

4) Mengenalkan mahasiswa kepada tugas dan peran

Langkah ini penting untuk merencanakan agar mahasiswa memiliki pemahaman yang jelas tentang peran mereka dan harapan-harapan dosen pada saat mereka berperan serta dalam suatu pelajaran pembelajaran kooperatif. Jika dosen lain di sekolah itu sedang menggunakan pembelajaran kooperatif, maka tugas ini menjadi lebih ringan karena mahasiswa telah siap dan mengetahui peran mereka dalam model pembelajaran ini, maka dosen harus meluangkan waktu khusus untuk menjelaskan model itu kepada mahasiswa dan melatih mereka keterampilan-keterampilan prasyarat.

5) Merencanakan waktu dan tempat

Pembelajaran kooperatif membutuhkan perhatian khusus dalam penggunaan ruang kelas, dan membutuhkan perabot yang dapat dipindahkan. Pada pengaturan ini dibagi atas dua cara yaitu:

a) model cluster

b) model swing

\section{METODE PENELITIAN}

Jenis penelitian ini adalah penelitian pengembangan (Research and Development) meliputi pengembangan Prototipe pembelajaran Matematika Komputasi yang terdiri dari Buku Ajar Mahasiswa (BM), Rencana Pelaksanaan Pembelajaran (RPP), Lembar Kegiatan Mahasiswa (LKM), dan Tes Hasil Belajar (THB).

Penelitian ini dilaksanakan di Kampus III Universitas Andi Djemma Palopo, dengan subjek penelitiannya adalah Mahasiswa semester 2 prodi Teknik Informatika Fakultas Teknik sebanyak 41 orang. Penelitian ini dilaksanakan pada semester genap tahun ajaran 2015/2016, dengan tiga tahap yaitu tahap persiapan, tahap pelaksanaan, dan tahap analisis data.

\section{Tahap persiapan}

Kegiatan yang dilaksanakan pada tahap ini adalah:

a. Menelaah Silabus semester genap untuk matakuliah Matematika Komputasi. 
b. Mengembangkan prototipe pembelajaran yaitu buku ajar mahasiswa, lembar kegiatan mahasiswa, rencana pelaksanaan pembelajaran, dan tes hasil belajar mahasiswa

c. Membuat lembar observasi untuk mengamati aktivitas mahasiswa, aktivitas dosen, dan pengelolaan pembelajaran di kelas.

d. Membuat angket untuk mengetahui respon mahasiswa tentang perangkat pembelajaran yang dikembangkan dengan model kooperatif tipe STAD.

\section{Tahap pelaksanaan}

Kegiatan yang dilakukan pada tahap ini adalah:

a. Membagi mahasiswa ke dalam beberapa kelompok secara heterogen.

b. Melaksanakan pembelajaran kooperatif tipe STAD.

c. Selama proses pembelajaran berlangsung dilakukan pengamatan aktivitas mahasiswa dan dosen serta kemampuan dosen mengelola pembelajaran yang dilakukan oleh satu orang pengamat.

\section{Tahap analisis data}

Kegiatan pada tahap ini adalah menganalisis data yang diperoleh dari tahap pelaksanaan. Data-data yang akan dianalisis adalah data hasil belajar mahasiswa, data hasil pengamatan aktivitas mahasiswa dan aktivitas dosen, dan data hasil pengamatan pengelolaan pembelajaran

\section{Desain Pengembangan Prototipe Pembelajaran Matematika Komputasi}

Pengembangan Prototipe pembelajaran matematika komputasi yang digunakan mengacu pada model 4-D Thiagarajan yang dimodifikasi. Hal ini disebabkan karena model 4-D Thiagarajan lebih terperinci dan lebih luas pengembangannya dibanding model yang lain.

Model ini merupakan sistem pendekatan pengembangan pembelajaran yang meliputi empat tahap yaitu: Pembatasan, Rancangan, Pengembangan dan Penyebaran. Untuk tahap penyebaran, belum dapat dilakukan dalam penelitian ini disebabkan karena keterbatasan waktu dan biaya yang dimiliki oleh peneliti.

\section{Desain Pengembangan Prototipe Pembelajaran}

Desain pengembangan prototipe pembelajaran dengan ujicoba terbatas digambarkan dengan diagram alur sebagai berikut: 


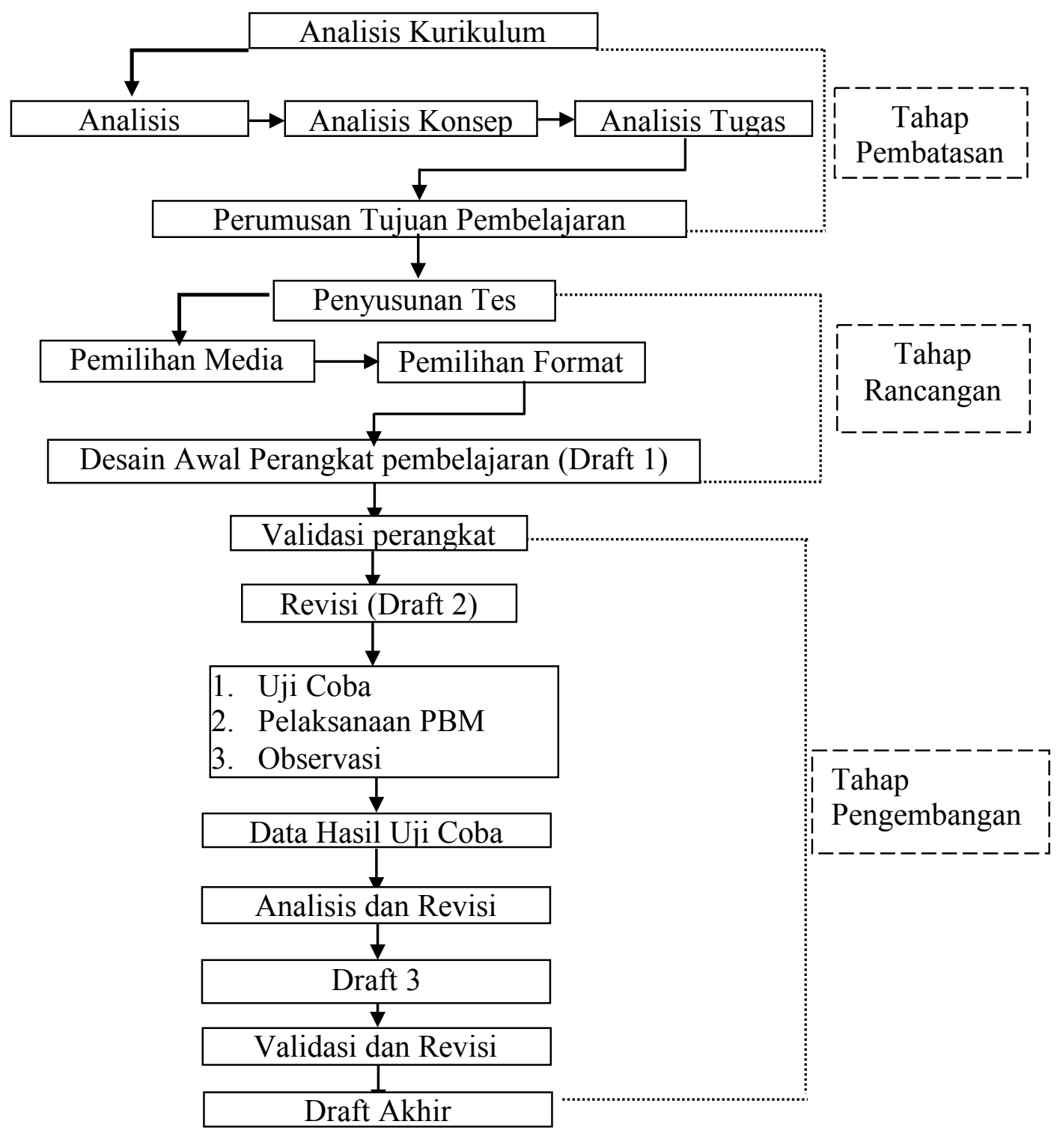

Diagram 1

Desain pengembangan prototipe pembelajaran matematika komputasi dengan ujicoba terbatas

\section{HASIL PENELITIAN}

Secara umum, hasil penilaian para pakar pendidikan terhadap prototipe pembelajaran kooperatif yang meliputi RPP, Buku Ajar Mahasiswa, LKM, dan Tes Hasil Belajar dapat dilihat pada tabel berikut: 
Tabel 2

Rangkuman Hasil Validasi Prototipe Pembelajaran

\begin{tabular}{|l|c|c|}
\hline \multicolumn{1}{|c|}{ Sumber } & Skor Rata-rata Penilaian & Status \\
\hline Buku Ajar Mahasiswa & 4,1 & Valid \\
\hline Lembar Kegiatan Mahasiswa & 4,1 & Valid \\
\hline Rencana Pelaksanaan Pembelajaran & 4,2 & Valid \\
\hline Tes Hasil Belajar & 4,2 & Valid \\
\hline
\end{tabular}

Berdasarkan tabel di atas, dapat disimpulkan bahwa secara umum penilaian atau hasil validasi dari para pakar pada prototipe pembelajaran yang dikembangkan meliputi Buku Ajar Mahasiswa, LKM, dan RPP berada pada kategori "Valid" $(3,5 \leq \bar{V}<4,5)$. Hal ini berarti Prototipe pembelajaran tersebut telah layak untuk diujicobakan.

\section{Ujicoba Terbatas}

Prototipe pembelajaran yang telah divalidasi dan direvisi (Draft 2) berdasarkan penilaian dan masukan dari para pakar pendidikan, selanjutnya diujicobakan terhadap 41 orang Mahasiswa semester II Prodi Teknik Informatika Fakultas Teknik Universitas Andi Djemma. Pada akhir ujicoba terbatas ini, seluruh mahasiswa diberikan tes hasil belajar yang bertujuan untuk mengukur tingkat penguasaan materi selama proses perkuliahan

Setelah perangkat pembelajaran (Draft 2) diujicobakan, dilakukan beberapa revisi untuk Buku Ajar Mahasiswa, LKM, RPP dan THB terutama dalam hal kesalahan pengetikan dan tata bahasanya. Namun secara umum, tidak banyak perubahan yang diberikan terhadap prototipe pembelajaran yang telah diujicobakan.

\section{PENUTUP}

\section{Kesimpulan}

Untuk mengembangkan Prototipe pembelajaran matematika komputasi menggunakan model kooperatif tipe STAD yang valid, praktis, dan efektif, maka dilakukan beberapa tahapan, diantaranya:

1. Memilih model pengembangan prototipe pembelajaran dengan mengkaji beberapa model pengembangan perangkat pembelajaran yang ada. Dalam hal pengembangan prototipe ini, digunakan model pengembangan Thiagarajan atau 4-D yang dimodifikasi. Model ini meliputi empat tahap yaitu tahap pembatasan (Define) yang mencakup lima langkah, yaitu: analisis awal akhir, analisis mahasiswa, analisis konsep, analisis tugas, dan spesifikasi tujuan pembelajaran; tahap perancangan (Design) yang mencakup empat langkah, yaitu: penyusunan tes, pemilihan media, pemilihan format, dan perencanaan awal; tahap pengembangan (Develop) yang mencakup dua langkah, yaitu: penilaian ahli dan ujicoba; dan tahap penyebaran (Disseminate), namun pada penelitian ini tahap penyebaran belum dapat dilaksanakan karena pelaksanaannya hanya berupa ujicoba terbatas saja. 
2. Membuat prototipe pembelajaran menggunakan model kooperatif tipe STAD pada matakuliah matematika komputasi yang meliputi:

a) Rencana Pelaksanaan Pembelajaran (RPP),

b) Buku Ajar Mahasiswa (BM),

c) Lembar Kegiatan Mahasiswa (LKM), dan

d) Tes Hasil Belajar.

3. Setelah prototipe pembelajaran divalidasi oleh para pakar pendidikan kemudian direvisi, prototipe pembelajaran yang meliputi RPP, BM, LKM, dan Tes Hasil Belajar dapat dinyatakan valid dan memenuhi syarat kelayakan untuk diujicobakan.

4. Dari hasil ujicoba diketahui bahwa prototipe pembelajaran kooperatif tipe STAD bersifat efektif dan praktis. Hasil ujicoba dapat diuraikan sebagai berikut:

a) Skor rata-rata yang diperoleh mahasiswa pada tes hasil belajar adalah 73,05 dari skor ideal 100 dengan standar deviasi 13,95. Terdapat 32 dari 41 mahasiswa atau sekitar 78,05\% memenuhi ketuntasan individu. Data ini menunjukan bahwa ketuntasan klasikal tercapai.

b) Dengan menggunakan perangkat pembelajaran kooperatif tipe STAD, minat serta motivasi mahasiswa dalam memahami konsep matematika menjadi meningkat. Hal ini terlihat bahwa 5 dari 9 kategori aktivitas mahasiswa yang diamati dengan kategori (3) aktif terlibat dalam tugas dan waktu ideal $15 \%$ dari WT, (4) aktif berdiskusi dengan teman dan waktu ideal 20\% dari WT, (7) Menjawab/menanggapi pertanyaan teman/dosen dan waktu ideal $8 \%$ dari WT, dan (8) memberi bantuan penjelasan kepada teman yang membutuhkan dan waktu ideal $20 \%$ dari WT yang menjadi syarat utama dalam kriteria memenuhi Interval Toleransi PWI (\%) yang ditentukan.

c) Secara umum, mahasiswa memiliki respons positif terhadap protipe pembelajaran kooperatif tipe STAD.

d) Dosen dapat membimbing kelompok bekerja dan belajar. Hal ini terlihat dari semua kategori aktivitas dosen yang diamati memenuhi Interval Toleransi PWI (\%) yang ditentukan, termasuk kategori (2), (4), (5), (6) dan (7) yang menjadi syarat utama juga terpenuhi.

e) Tingkat kemampuan dosen dalam mengelola proses pembelajaran kooperatif tipe STAD termasuk dalam kategori sangat tinggi dengan rata-rata yang diperoleh adalah 3,51 , artinya penampilan dosen dapat dipertahankan.

\section{Saran}

1. Prototipe pembelajaran yang dihasilkan sebaiknya dilanjutkan pada tahap penyebaran sehingga dapat digunakan khususnya pada kelas-kelas dan umumnya pada sekolah-sekolah yang lain.

2. Para dosen matematika atau mahasiswa sebaiknya mengembangkan perangkat pembelajaran matematika pada matakuliah lain dengan melakukan ujicoba berkali-kali sehingga didapatkan prototipe pembelajaran yang layak untuk digunakan dan dilakukan sampai pada tahap penyebaran. 


\section{DAFTAR PUSTAKA}

Arikunto, Suharsimi. 2010. Dasar-dasar Evaluasi pendidikan. Jakarta: Bumi Aksara.

Balitbang Depdiknas. 2006. Panduan Penilaian Berbasis Kelas. Jakarta: Depdiknas.

Hisyam, Darwis, M., \& Ruslan. 2011. Pengembangan Model Pembelajaran Matematika yang Berbasis Kinerja Siswa. Penelitian Hibah Bersaing DIKTI. Tidak diterbitkan. Makassar: Universitas Negeri Makassar.

Khabib, Zaenal \& Janet Trineke Manoy. 2013. Pengembangan Perangkat Pembelajaran dengan Pendekatan RMT Ditinjau dari Fungsi Kognitif Siswa pada Materi Melukis Segitiga di Kelas VII SMP. Surabaya: FMIPA UNESA

Mansyur. 2011. Pengembangan Model Assessment for Learning pada Pembelajaran Matematika Di SMP. Jurnal Penelitian dan Evaluasi Pendidikan, 15 (1), $\quad 71$ - 91.

Mertayasa, Dewa Made. 2012. Pengembangan Perangkat Pembelajaran Matematika Berorientasi Masalah Realistik untuk Model Pembelajaran Peningkatan Kemampuan Berpikir Sebagai Upaya Meningkatkan Hasil Belajar Matematika Siswa Kelas VIII. PPs Universitas Pendidikan Ganesha

Muslich, Masnur. 2007. KTSP: Dasar Pemahaman dan Pengembangan. Jakarta: PT Bumi Aksara. Mustamin, St Hasmiah. 2010. Meningkatkan Hasil Belajar Matematika Melalui Penerapan Asesmen Kinerja. Lentera Pendidikan Vol. 13 No. 1, Juni 2010. Makassar: Universitas Negeri Makassar

Nurdin. 2007. Model Pembelajaran Matematika yang Menumbuhkan Kemampuan Metakognitif untuk Menguasai Bahan Ajar. Disertasi tidak diterbitkan. Surabaya: UNESA

Prawiradilaga, Dewi Salma. 2007. Prinsip Disain Pembelajaran. Jakarta: Kencana.

Rahayu, Dwi Shinta. 2011. Pengembangan Perangkat Penilaian Proyek Berbahasa Inggris Pada Materi Skala (Online), (http://ejournal.unesa.ac.id/index.php/ mathedunesa/article/view/244/pdf, Diakses pada 10 Oktober 2013)

Rochmad. 2012. Pengembangan Model Pembelajaran: Mengacu Pada Plomp (Online), (http://blog.unnes.ac.id/rochmad/files/2011/03/Model-pengembangan-plompRochmad-Unnes.pdf, Diakses pada 16 Oktober 2013).

Ruslan. 2005. Prinsip Dasar Evaluasi. Disampaikan pada Diklat Guru Sekolah Dasar Mata Pelajaran Matematika. Makassar : Lembaga Penjamin Mutu Pendidikan. . 2009. Validitas Isi. Buletin Pa'biritta No. 10 Tahun VI September 2009

Setyosari, Punaji. 2010. Metode Penelitian Pendidikan dan Pengembangan. Jakarta: Kencana Sudijono, Anas. 2011. Pengantar Evaluasi Pendidikan. Jakarta: PT RajaGrafindo Persada Wardhani, Sri. 2010. Teknik Pengembangan Instrumen Penilaian Hasil Belajar Matematika Di SMP/MTs. Yogyakarta: Depdiknas. 